\title{
Interferon Enhances Prostacyclin Production by Cultured Vascular Endothelial Cells
}

\author{
Amiram Eldor, Rafael Fridman, Israel Vlodavsky, \\ Esther Hy-Am, Zvi Fuks, and Amos Panet \\ Department of Hematology and Department of Radiation and \\ Clinical Oncology, Hadassah University Hospital, Jerusalem, \\ Israel; Department of Virology, The Hebrew University-Hadassah \\ Medical School, Jerusalem, Israel
}

bstract. The effects of interferon (IFN) on the arachidonate metabolism and physiological functions of cultured endothelial cells and blood platelets have been examined. Cultured bovine aortic endothelial cells were found to be sensitive to the antiviral and antiproliferative activities of human leukocyte ( $\alpha$ ) IFN and to increase their capacity to synthesize prostacyclin $\left(\mathrm{PGI}_{2}\right)$ upon exposure to IFN. Several observations indicate that IFN stimulates $\mathrm{PGI}_{2}$ synthesis at the level of the enzymes phospholipase $\mathrm{A}_{2}$ and cyclooxygenase: (a) $\mathrm{PGI}_{2}$ production was dependent upon the supply of exogenous arachidonic acid or the liberation of endogenous cellular arachidonate by ionophore A23187, but was not observed when IFN-treated cells were exposed to the endoperoxide prostaglandin $\mathbf{H}_{2}$. (b) IFN had no effect on the spontaneous release of $\mathrm{PGI}_{2}$ into the culture medium during the incubation period (24-72 h). (c) The stimulatory effect of IFN on $\mathrm{PGI}_{2}$ production was inhibited by both glucocorticoids and indomethacin. The effect of IFN on platelet prostaglandin metabolism was also investigated. Incubation of platelet-rich plasma with IFN had no effect on platelet aggregation and thromboxane $A_{2}$ production. The biological significance of the findings presented in this paper may be considered in view of the protective role of $\mathrm{PGI}_{2}$ in the vessel wall and the fact that infection with certain viruses induces endothelial damage both in man and experimental animal models.

\footnotetext{
This work was presented in part in the IXth International Congress on Thrombosis and Haemostasis, July 3, 1983.

Received for publication 6 July 1983 and in revised form 21 September 1983.
}

J. Clin. Invest.

(C) The American Society for Clinical Investigation, Inc. 0021-9738/84/01/0251/07 \$1.00

Volume 73, January 1984, 251-257

\section{Introduction}

Endothelial cells line the inner surface of blood vessels and form a protective barrier between the circulating blood and the vessel wall. In some patients, certain viral infections such as arboviruses (dengue virus), varicella, variola, and rubella lead to endothelial damage resulting in hemorrhagic manifestations or the formation of platelet thrombi at sites of damage (1). The vascular endothelium has also been shown to be susceptible to viral infections in certain experimental models. Infection with SV40 virus results in endothelial transformation and impairment of its nonthrombogenic properties (2). Infection with Marek's disease herpes virus leads to the development of occlusive atherosclerosis in chickens (3).

One of the protective mechanisms of the vessel wall against thrombosis and platelet deposition is the capacity of the endothelial cells to produce a unique prostaglandin (PG), prostacyclin $\left(\mathrm{PGI}_{2}\right)^{1}(4)$. $\mathrm{PGI}_{2}$ is synthesized from arachidonic acid by the arterial wall and is a most potent vasodilator and inhibitor of platelet aggregation (4). On the other hand, platelets produce thromboxane $\mathrm{A}_{2}\left(\mathrm{TXA}_{2}\right)$, which promotes platelet aggregation and functions as a potent vasoconstrictor (5). Thus a balance between $\mathrm{PGI}_{2}$ and $\mathrm{TXA}_{2}$ is considered important in maintaining the vessel wall integrity.

During certain viral infections the endothelial cells are exposed to circulating interferon (IFN) induced by the virus (6). IFN has been shown to stimulate production of prostaglandin $E$ in human fibroblasts and a similar effect has also been observed with IFN-inducers such as poly (I): poly (C) and viruses (7-9). The purpose of the present study was to examine whether IFN modulates the production of $\mathrm{PGI}_{2}$ by endothelial cells and of $\mathrm{TXA}_{2}$ by platelets, and hence affects the integrity of the vessel wall.

1. Abbreviations used in this paper: BAEC, bovine aortic endothelial cell; DME-H16, Dulbecco's modified Eagle's medium; IFN, interferon; PG, prostaglandin; PGA, $\mathrm{PGE}_{2}, \mathrm{PGF}$, and $\mathrm{PGH}_{2}$, prostaglandins $\mathrm{A}, \mathrm{E}$, $\mathrm{F}$, and $\mathrm{H} ; \mathrm{PGI}_{2}$, prostacyclin; $\mathrm{PRP}$, platelet-rich plasma; $6 \mathrm{KF}, 6$-keto$\mathrm{PGF}_{1 \alpha}$; STV, saline-trypsin-versen; $\mathrm{TXA}_{2}$ and $\mathrm{TXB}_{2}$; thromboxane $\mathrm{A}_{2}$ and $B_{2} ; \mathrm{VSV}$, vesicular stomatitis virus. 


\section{Methods}

Materials. Dulbecco's modified Eagle's medium (DME-H16) and calf serum were obtained from Grand Island Biological Co., (Gibco) Grand Island, NY; [ $\left.{ }^{3} \mathrm{H}\right] 6$-keto-PGF ${ }_{1 \alpha}(6 \mathrm{KF}),\left[{ }^{3} \mathrm{H}\right]$ thromboxane $\mathrm{B}_{2}\left(\mathrm{TXB}_{2}\right)$, and $\left[{ }^{3} \mathrm{H}\right] \mathrm{PGE}_{2}$ were from New England Nuclear, Boston, MA; arachidonic acid, ionophore A23187, ADP, and indomethacin were from Sigma Chemical Co., St. Louis, MO; collagen was from Hormon Chemie, Munich, Federal Republic of Germany; $\mathrm{PGH}_{2}$ was kindly given by Dr. A. Raz, Tel Aviv University; and antisera for $6 \mathrm{KF}$ and $\mathrm{TXB}_{2}$ were a gift from Dr. B. B. Weksler, Cornell University, NY. Hydrocortisone, progesterone, and dexamethasone were from Ikapharm, Israel. Human leukocyte $(\alpha)$ IFN $\left(3.6 \times 10^{6} \mathrm{U} / \mathrm{mg}\right)$, a gift from Dr. T. Bino, The Biological Institute, Nes-Ziona, was prepared and purified as described before (10). Mouse IFN produced in L cells $\left(1 \times 10^{7} \mathrm{U} / \mathrm{mg}\right)$ was purified according to Paucker et al. (11). Vesicular stomatitis virus (VSV) was propagated and titrated in mouse $L$ cells. Fibroblast growth factor (FGF) was purified from bovine brain as described (12).

Cells. Clonal populations of bovine vascular endothelial cells derived from the adult aortic arch were obtained as previously described (13, 14). Cells were routinely cultured in DME-H16 supplemented with $10 \%$ calf serum and gentamycin $(50 \mu \mathrm{g} / \mathrm{ml})$ at $37^{\circ}$ in $10 \% \mathrm{CO}_{2}$-humidified incubators. Cells were dissociated weekly with STV (saline-trypsin-versen) (0.05\% trypsin/0.02\% EDTA in phosphate-buffered saline), split at a ratio of 1 to 64 , and FGF $(100 \mathrm{ng} / \mathrm{ml})$ was added to the culture medium every other day during the phase of active cell growth. Confluent cultures $\left(1,100 \mathrm{cells} / \mathrm{mm}^{2}\right)$ were kept without further addition of FGF. At confluence the cells form a monolayer composed of nonoverlapping and closely apposed cells that express differentiated features such as a nonthrombogenic apical surface, active production of $\mathrm{PGI}_{2}$, Factor VIII antigen, and a polar secretion of an underlying extracellular matrix similar in organizaton and chemical composition (collagen type IV and $\mathrm{V}$, heparan sulfate, laminin, and fibronectin) to naturally occurring basal laminas (13-15). For the experiments, cell monolayers from stock plates were dissociated with STV and $4 \times 10^{4}$ cells were seeded into each 35 $\mathrm{mm}$ dish and cultured as described above. Most experiments were performed 7-8 d after the cells reached confluence. Hela cells were cultured in DME-H16 supplemented with $10 \%$ bovine calf serum, and in the absence of FGF.

Release and synthesis of prostaglandins by endothelial cells. Endothelial cells were incubated in the presence or absence of IFN and the amount of spontaneously released PG was determined in samples of the culture medium withdrawn at the end of the incubation period. For the assessment of de novo PG synthesis, the culture medium was first removed and the cell monolayers washed twice with warm Hepesbuffered saline $\left(37^{\circ} \mathrm{C}, \mathrm{pH} 7.5\right)$ containing $1 \mathrm{mM} \mathrm{MgCl}_{2}, 1.8 \mathrm{mM} \mathrm{CaCl}_{2}$, and $5 \mathrm{mM}$ glucose (buffer $\mathrm{A}$ ). PG production was stimulated by either arachidonic acid $(20 \mu \mathrm{M}$ from $2 \mathrm{mM}$ stock solution prepared in $0.1 \mathrm{~N}$ $\mathrm{Na}_{2} \mathrm{CO}_{3}$ ), ionophore $\mathrm{A} 23187(5 \mu \mathrm{M})$, or $\mathrm{PGH}_{2}(5 \mu \mathrm{M})$. These reagents were added at the indicated concentrations to $1 \mathrm{ml}$ of buffer $\mathrm{A}$ and incubated with the washed monolayers for $2 \mathrm{~min}$ at $37^{\circ} \mathrm{C}$. The supernatant fluids were then removed, frozen immediately in liquid nitrogen, and kept at $-70^{\circ} \mathrm{C}$ until used. The cells were then dissociated with STV and counted with a Coulter counter. (Coulter Electronics, Inc., Hialeah, FL) For each data point four to six culture dishes were used.

Platelet aggregation. Venous blood from normal donors who had not ingested aspirin-containing drugs for $10 \mathrm{~d}$ was drawn by a twosyringe technique and mixed with 0.1 vol of $3.2 \%$ trisodium citrate. Platelet-rich plasma (PRP) was prepared by centrifugation of blood at $150 \mathrm{~g}$ for $10 \mathrm{~min}$ at room temperature and was kept tightly capped under $5 \% \mathrm{CO}_{2}-95 \%$ air mixture until use. Platelet-poor plasma was prepared by centrifugation of PRP for $1 \mathrm{~min}$ in an Ependorf 5414 microfuge.

Platelet aggregation studies were performed using 0.4-ml aliquots of PRP stirred at $1,000 \mathrm{rpm}$ at $37^{\circ} \mathrm{C}$ in siliconized cuvettes in a Payton 800 aggregometer (Payton Associates, NY). The cell count in PRP was determined using a Coulter counter (Coulter Electronics, Inc.) and averaged $4 \times 10^{8}$ platelets $/ \mathrm{ml}$. PRP was incubated (room temperature, 1$24 \mathrm{~h}$ ) in the presence or absence of IFN and then stirred in the aggregometer for $5 \mathrm{~min}$, following which Hepes buffer and the aggregating agent were added in a total volume of $0.1 \mathrm{ml}$. Extent of aggregation was calculated as the percentage of the change in light transmission at $5 \mathrm{~min}$ after the addition of the stimulus relative to the full range between PRP and platelet-poor plasma. For determination of $\mathrm{TXB}_{2}$ levels, 0.1$\mathrm{ml}$ aliquots were then withdrawn from the aggregation cuvette and quenched with $0.9 \mathrm{ml}$ of $0.1 \mathrm{M}$ phosphate-buffered saline containing $10^{-4} \mathrm{M}$ indomethacin, and then frozen in liquid $\mathrm{N}_{2}$. Samples were stored in $-70^{\circ} \mathrm{C}$ until assayed for $\mathrm{TXB}_{2}$ by a radioimmunoassay.

Quantitation of $P G$ s. $\quad \mathrm{PGI}_{2}$ and $\mathrm{TXA}_{2}$ were quantitated in the culture medium or cell supernatants (following stimulation) by radioimmunoassays of their respective hydration products $6 \mathrm{KF}$ and $\mathrm{TXB}_{2}$ as previously described (15). $\mathrm{PGE}_{2}$ was also quantitated in these fluids by radioimmunoassay (15).

Statistical methods. Data were analyzed by the independent Student's $t$ test and by one-way analysis of variance (Kruskall Wallis).

\section{Results}

Sensitivity of bovine aortic endothelial cells (BAEC) to IFN. The sensitivity of bovine cells to human IFN has been previously reported (16). To establish the sensitivity of BAEC to human leukocyte IFN, we compared the IFN's protection against the cytopathic effect of VSV in BAEC and HeLa cells (Fig. 1).

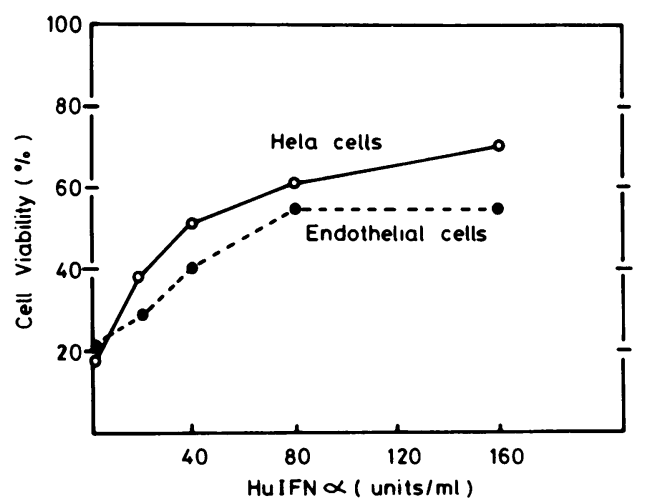

Figure 1. IFN's protection against the cytopathic effect of VSV replication in BAEC and HeLa cells. $10^{5}$ cells were plated (without FGF) into 16-mm multiwell dishes and confluent cultures were treated for $24 \mathrm{~h}$ with increasing concentrations of IFN. Cultures were then infected with VSV at a multiplicity of infection of one and the cytopathic effect was estimated $24 \mathrm{~h}$ later by staining the cultures for viable cells with neutral red as described by Borden et al. (17). The amount of stain absorbed by the culture was determined at $A=540$ $\mathrm{nm}$. Absorbance of control cultures not infected with the virus represents $100 \%$ viability. 
Pretreatment with 40 and $20 \mathrm{U} / \mathrm{ml}$ of IFN was necessary to protect $50 \%$ of BAEC and HeLa cells, respectively, from the cytopathic effect of VSV, indicating a similar dose-response effect of IFN on both bovine and human cells.

Fig. 2 shows that IFN markedly inhibited the rate of endothelial cell proliferation. The saturation density of cells treated with the high IFN $(2,000 \mathrm{U} / \mathrm{ml})$ concentration was decreased by threefold compared with untreated cultures, thus demonstrating the antiproliferative effect of IFN on bovine cells. In this experiment FGF was present during the phase of active cell growth, both in the control and cultures treated with IFN. When the concentration of FGF was increased up to $1,000 \mathrm{ng} / \mathrm{ml}$, the antiproliferative effect of IFN was less pronounced (data not shown).

Effect of IFN on $\mathrm{PGI}_{2}$ production. Confluent BAEC cultures were incubated with IFN, and both the accumulation of $\mathrm{PGI}_{2}$ spontaneously released into the culture medium and the stimulated production of $\mathbf{P G I}_{2}$ were evaluated. Fig. 3 shows an experiment performed with confluent BAEC cultures that were preincubated with IFN $(1,000 \mathrm{U} / \mathrm{ml})$ for $24 \mathrm{~h}$. There was no increase in the spontaneous release of $\mathrm{PGI}_{2}$ into the medium when the cultures were treated with IFN. However, when the cells were exposed to exogenous arachidonic acid $(20 \mu \mathrm{M}, 2$ min), a fourfold increase in $\mathrm{PGI}_{2}$ production was noted with

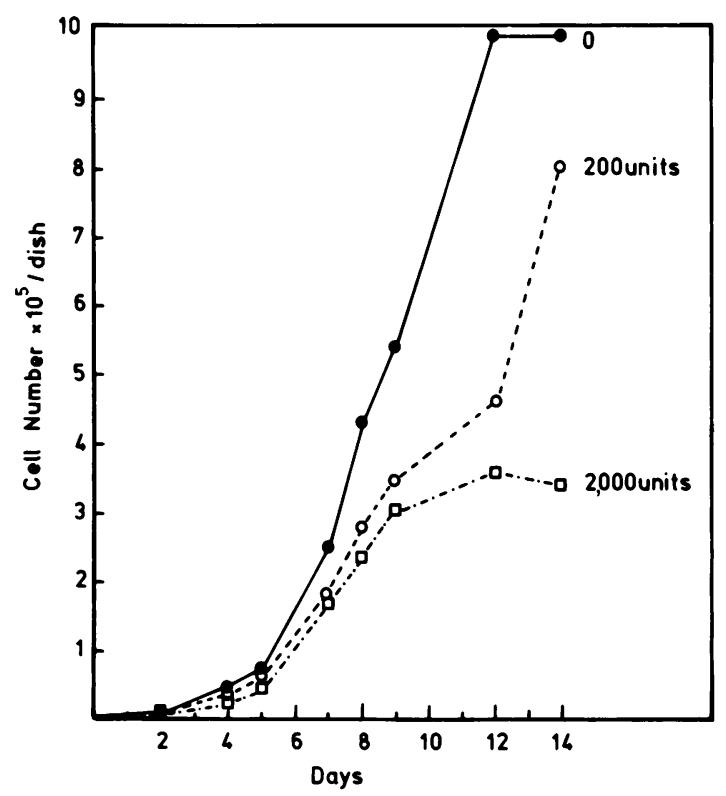

Figure 2. Inhibition of BAEC proliferation by IFN. $5 \times 10^{3}$ BAEC were plated per $35-\mathrm{mm}$ dishes. IFN ( 200 or $2,000 \mathrm{U} / \mathrm{ml}$ ) was added to some of the dishes $24 \mathrm{~h}$ after seeding and every $3 \mathrm{~d}$ thereafter. FGF $(100 \mathrm{ng} / \mathrm{ml})$ was added to the cultures $24 \mathrm{~h}$ after seeding and every other day thereafter. At various times after seeding the cells were dissociated with STV and counted with a Coulter counter (Coulter Electronics, Inc.). Three culture dishes were used for each determination and the variation in different determinations did not exceed $\pm 10 \%$ of the mean.

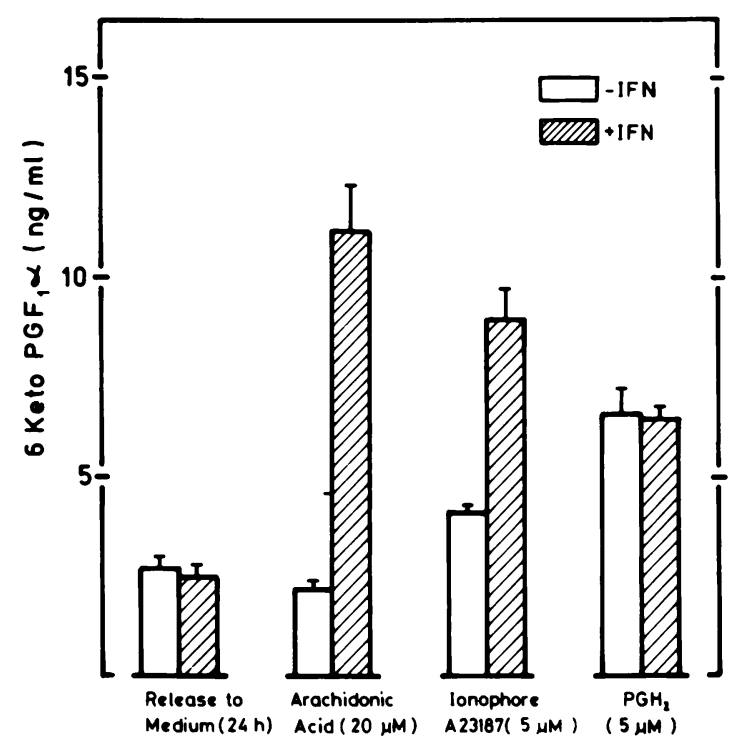

Figure 3. Effect of IFN on the spontaneous release and stimulated production of $\mathrm{PGI}_{2}$. Confluent BAEC cultures ( $14 \mathrm{~d}$ after seeding, $1.05 \times 10^{6}$ cells $/ 35-\mathrm{mm}$ dish) were incubated for $24 \mathrm{~h}$ with IFN $(1,000 \mathrm{U} / \mathrm{ml})$. The growth medium was collected and assayed for $6 \mathrm{KF}$ content, and the cell monolayers were stimulated $\left(2 \mathrm{~min}, 37^{\circ} \mathrm{C}\right)$ with either arachidonic acid $(20 \mu \mathrm{M})$, ionophore A23187 $(5 \mu \mathrm{M})$, or $\mathrm{PGH}_{2}(5 \mu \mathrm{M})$. Six culture dishes were used for each data point, and bars represent mean \pm SEM.

IFN-pretreated cells as compared with cells not exposed to IFN. Similarly, IFN-treated cells stimulated with ionophore A23187, which induces the release of endogenous arachidonic acid from cellular lipids (18), also produced significantly higher amounts of $\mathrm{PGI}_{2}$ compared with untreated cells. In contrast, IFN had no effect on the production of $\mathrm{PGI}_{2}$ stimulated by incubation with the endoperoxide $\mathrm{PGH}_{2}$, which is a substrate for the enzyme $\mathrm{PGI}_{2}$ synthetase (19).

The IFN-mediated enhancement of $\mathrm{PGI}_{2}$ production was less pronounced when the cells were exposed to IFN for periods shorter than $24 \mathrm{~h}$. Incubation with IFN for longer periods of time (up to $72 \mathrm{~h}$ ) did not significantly increase the $\mathrm{PGI}_{2}$ production over the amounts found at $24 \mathrm{~h}$ (data not shown). The enhancement of the arachidonate-dependent $\mathrm{PGI}_{2}$ production was dependent on the concentration of IFN in a dose-response manner, and maximal stimulation was observed after treatment with $500-1,000 \mathrm{U} / \mathrm{ml}$ of IFN (Fig. 4). Addition of FGF to the confluent endothelial cell cultures did not change the enhancing effect of IFN on the capacity of the cells to produce $\mathrm{PGI}_{2}$ (data not shown). Bovine endothelial cells have a limited capacity to produce $\mathrm{TXA}_{2}$ and $\mathrm{PGE}_{2}$ (15). Preincubation with IFN did not result in a significant increase in the residual synthetic capacity of the cells for these PG (Fig. 4).

The effect of IFN was also tested on subconfluent and not yet organized BAEC cultures where preincubation with IFN also resulted in the inhibition of cell proliferation, as shown in 


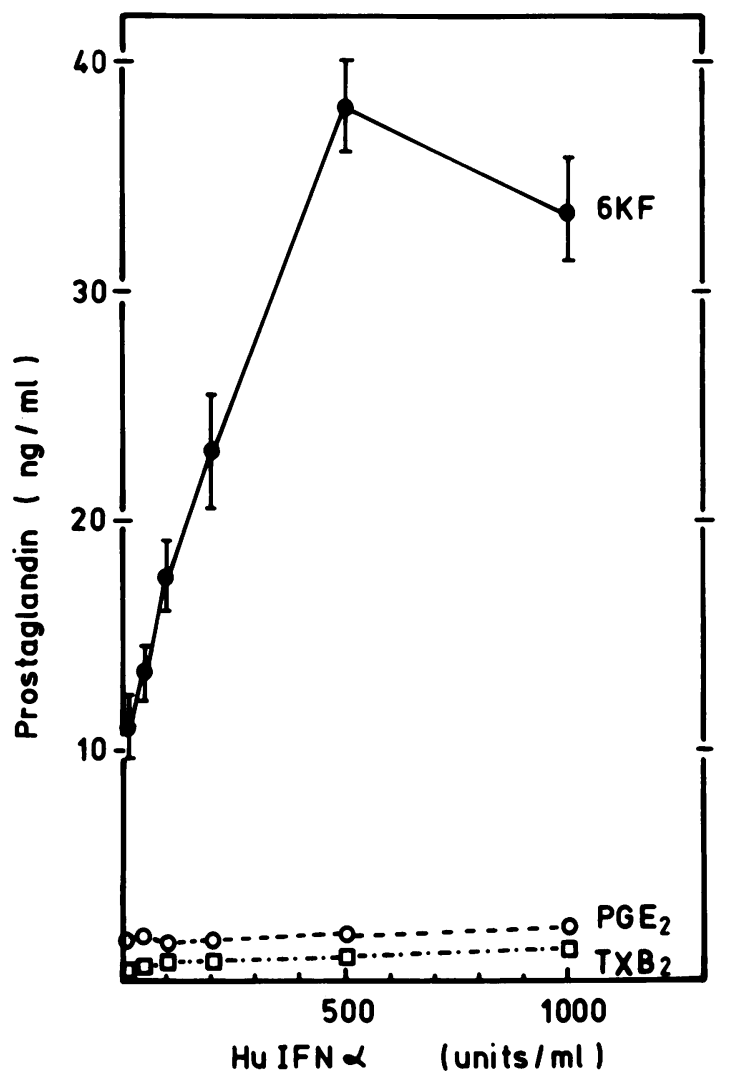

Figure 4. Dose response effect of IFN on the capacity of BAEC to produce PG. Confluent monolayers of BAEC (14 d after seeding) were incubated for $48 \mathrm{~h}$ with IFN. The cultures were washed and PG production was stimulated by adding arachidonic acid $(20 \mu \mathrm{M}, 2$ $\mathrm{min}$ ). Supernatant fluids were collected and assayed for $6 \mathrm{KF}, \mathrm{TXB}_{2}$, or $\mathrm{PGE}_{2}$. Control and IFN-treated cells contained $1 \pm 0.1 \times 10^{6}$ cells/ 35-mm dish. Six culture dishes were used for each data point and bars represent mean \pm SEM.

Fig. 2. 4-d-old BAEC cultures were treated with IFN (1,000 U/ $\mathrm{ml}, 72 \mathrm{~h}$ ), washed, and stimulated with arachidonic acid (20 $\mu \mathrm{M}, 2 \mathrm{~min})$. IFN-treated cultures $\left(5.6 \times 10^{5} \mathrm{cells} /\right.$ dish $)$ produced $11.3 \pm 1.1 \mathrm{ng} / \mathrm{ml} 6 \mathrm{KF}($ mean $\pm \mathrm{SD})$ while the control cultures $(9.4$ $\times 10^{5}$ cells/dish) produced only $6.2 \pm 1.1 \mathrm{ng} / \mathrm{ml} 6 \mathrm{KF}(P<0.01)$.

When IFN was replaced with mouse IFN, which does not induce antiviral activity in bovine cells (16), no increase was observed in the $\mathrm{PGI}_{2}$ production capacity of the BAEC (Table I). Preincubation of IFN at pH 2.5 did not affect its stimulatory effect on $\mathrm{PGI}_{2}$ production, while pretreatment with trypsin abolished this IFN activity (Table I). These results suggest that the effect on BAEC is specific to IFN and is not due to contaminants.

Effect of inhibitors on PG synthesis. Hydrocortisone and dexamethasone, inhibitors of phospholipase $\mathrm{A}_{2}$, produced a significant inhibition $(P<0.01)$ of the enhanced synthesis of $\mathrm{PGI}_{2}$ observed in IFN-treated BAEC. In contrast progesterone, which
Table I. Effect of Various Pretreatments of IFN on Its Stimulation of $\mathrm{PGI}_{2}$ Production

\begin{tabular}{llr}
\hline & Pretreatment & \multicolumn{1}{l}{$6 \mathrm{KF}$} \\
\hline & & $n g / m l$ \\
Control & - & $2.98 \pm 0.5$ \\
IFN & - & $11.81 \pm 1.4$ \\
IFN & pH 2.5 & $8.15 \pm 0.8$ \\
IFN & Trypsin & $2.32 \pm 0.1$ \\
Mouse IFN & - & $2.63 \pm 0.4$ \\
\hline
\end{tabular}

14-d confluent BAEC cultures $\left(1.1 \times 10^{6}\right.$ cells/dish $)$ were incubated for $24 \mathrm{~h}$ with untreated or treated IFN $(500 \mathrm{U} / \mathrm{ml})$, washed twice with Hepes-buffered saline, and stimulated with arachidonic acid $(20 \mu \mathrm{M}, 2$ min, $37^{\circ} \mathrm{C}$ ). $6 \mathrm{KF}$ was measured by radioimmunoassay. Each data point represents the mean $\pm \mathrm{SD}$ of the results obtained from five culture dishes. IFN $(1,000 \mathrm{U} / \mathrm{ml})$ was pretreated with trypsin $(0.025 \%)$ or with $0.1 \mathrm{M}$ sodium acetate buffer, $\mathrm{pH} 2.5$, for $1 \mathrm{~h}$ at $37^{\circ} \mathrm{C}$ and diluted twofold with medium-containing serum. The concentration of mouse IFN was 500 $\mathrm{U} / \mathrm{ml}$.

has no inhibitory effect on phospholipase $A_{2}$, did not inhibit the effect of IFN (Fig. 5). Control cultures not treated with IFN did not show a significant change in their $\mathbf{P G I}_{2}$ production

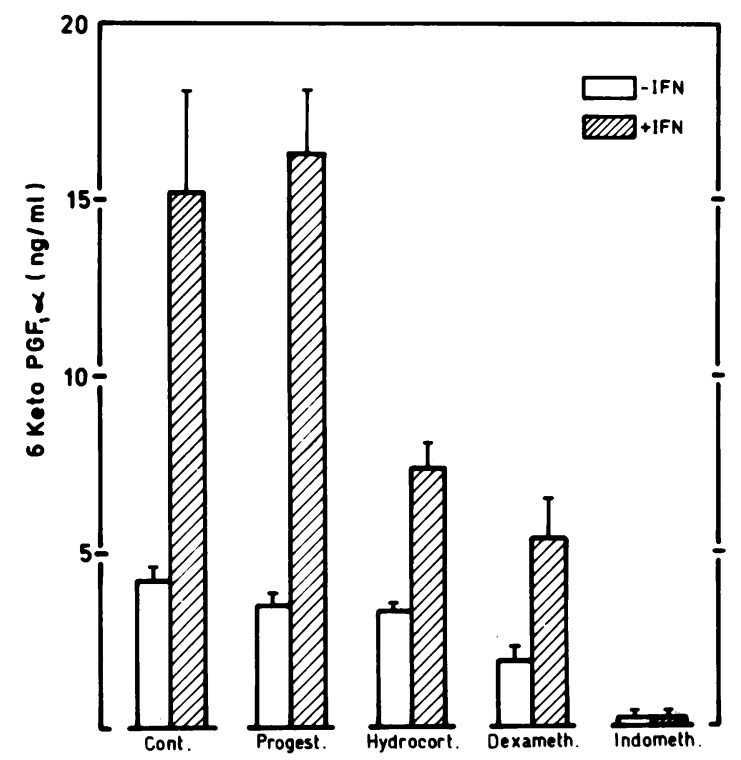

Figure 5. Effect of steroid hormones and indomethacin on the IFNstimulated production of $\mathrm{PGI}_{2}$. Confluent BAEC cultures ( $14 \mathrm{~d}$ after seeding, $1.2 \times 10^{6}$ cells/dish) were incubated for $72 \mathrm{~h}$ with IFN $(1,000 \mathrm{U} / \mathrm{ml})$ in the absence (control) or presence of either progesterone $(2 \mu \mathrm{g} / \mathrm{ml})$, hydrocortisone $(2 \mu \mathrm{g} / \mathrm{ml})$, dexamethasone (2 $\mu \mathrm{g} / \mathrm{ml})$, or with indomethacin $(1 \mu \mathrm{g} / \mathrm{ml})$. At the end of the incubation, the cultures were washed and stimulated with arachidonic acid $(20 \mu \mathrm{M}, 2 \mathrm{~min})$. Supernatant fluids were assayed for $6 \mathrm{KF}$. Six culture dishes were used for each data point, and bars represent mean \pm SEM. 
capacity upon exposure to both glucocorticoids. Indomethacin, a potent inhibitor of fatty acid cyclooxygenase, completely inhibited $\mathrm{PGI}_{2}$ production in both the control and IFN-treated cells (Fig. 5).

Effect of IFN on platelet aggregation and TXA formation. Since IFN stimulated $\mathrm{PGI}_{2}$ production by endothelial cells, it was of interest to investigate its effect on $\mathrm{TXA}_{2}$ production, in resting and stimulated platelets. As platelets are devoid of nuclei, possible effects of IFN are expected to directly affect their membrane. In fact, rapid effects of IFN occurring within $5 \mathrm{~min}$ of exposure to cells have been reported $(20,21)$. Such activities of IFN may not require gene induction and thus nuclear involvement. Human platelets were incubated with IFN (500$5,000 \mathrm{U} / \mathrm{ml}, 37^{\circ} \mathrm{C}$ ) for up to $60 \mathrm{~min}$, tested for aggregability, and aliquots were removed for determination of $\mathrm{TXA}_{2}$. The addition of IFN did not result in platelet aggregation nor were the levels of $\mathrm{TXB}_{2}$ measured at the end of $5 \mathrm{~min}$ of stirring different from those found with platelets not treated with IFN (Table II). Preincubation $\left(60 \mathrm{~min}, 22^{\circ} \mathrm{C}\right)$ with IFN $\left(10^{3} \mathrm{U} / \mathrm{ml}\right)$ did not affect platelet aggregation or $\mathrm{TXB}_{2}$ production in either unstimulated platelets or platelets that were stimulated with either arachidonic acid (at subthreshold or aggregating concentrations), collagen, or ADP. The levels of $\mathrm{TXB}_{2}$ measured in PRP that was preincubated (at room temperature with gentle swirling) with $5,000 \mathrm{U} / \mathrm{ml} \mathrm{IFN}$ for $24 \mathrm{~h}$ were not different from those observed in control PRP. These platelets were not responsive to the aggregating agents when tested after the 24-h incubation period. Similar results were observed with PRP obtained from five healthy donors, indicating that IFN has no effect on platelet reactivity and thromboxane production in vitro.

Table II. Effect of IFN Treatment on Platelet Aggregation and $T X B_{2}$ Production

\begin{tabular}{|c|c|c|c|c|}
\hline \multirow[b]{2}{*}{ Aggregating agent } & \multicolumn{2}{|c|}{ Aggregation } & \multicolumn{2}{|c|}{$\mathrm{TXB}_{2}$} \\
\hline & $-\mathrm{IFN}$ & + IFN & $-\mathrm{IFN}$ & + IFN \\
\hline & \multicolumn{2}{|c|}{$\%$} & \multicolumn{2}{|c|}{$n g / m l$} \\
\hline- & 0 & 0 & 1.8 & 1.6 \\
\hline $\begin{array}{l}\text { Arachidonic acid } \\
\left(1 \times 10^{-4} \mathrm{M}\right)\end{array}$ & 0 & 0 & 15.8 & 16.8 \\
\hline $\begin{array}{l}\text { Arachidonic acid } \\
\qquad\left(3 \times 10^{-4} \mathrm{M}\right)\end{array}$ & 70 & 65 & 262.2 & 245.4 \\
\hline Collagen $(1 \mu \mathrm{g} / \mathrm{ml})$ & 40 & 46 & 16.9 & 13.5 \\
\hline $\operatorname{ADP}\left(1.2 \times 10^{-5} \mathrm{M}\right)$ & 43 & 47 & 8.5 & 8.8 \\
\hline
\end{tabular}

PRP was incubated with and without IFN $\left(5,000 \mathrm{U} / \mathrm{ml}, 60 \mathrm{~min}, 22^{\circ} \mathrm{C}\right)$ and then stirred in the aggregometer for another $5 \mathrm{~min}\left(37^{\circ} \mathrm{C}\right)$. Aggregation was recorded for $5 \mathrm{~min}$ after the addition of the aggregating agent or a control buffer (final volume $0.5 \mathrm{ml}$ ) and $0.1-\mathrm{ml}$ aliquots were removed for $\mathrm{TXB}_{2}$ quantitation as detailed in Methods. Similar results were obtained with lower concentrations of IFN $(500,1,000$, and 2,000 U/ml) and at incubation periods shorter than $60 \mathrm{~min}$.

\section{Discussion}

The production of $\mathrm{PGI}_{2}$ by endothelial cells is regarded as one of the important mechanisms for preventing the deposition of platelets on the vessel wall $(4,18)$. PGI $_{2}$ synthesis and release are stimulated when endothelial cells are acutely injured, as previously demonstrated in vitro with cultured endothelial cells subjected to mechanical or radiation-induced damage (22). In the vessel wall, endothelial injury is also associated with local platelet deposition and release of constituents such as plateletderived growth factor and PG endoperoxides $(5,23)$. These compounds can further stimulate $\mathrm{PGI}_{2}$ production by adjacent noninjured endothelial cells $(24,25)$. Several other plasma components (triiodothyronine, estrogens, angiotensin II, bradykinine, and high density lipoprotein) have been shown to stimulate the vascular cells to produce $\mathrm{PGI}_{2}$ (for review see reference 26 ). The present study shows that IFN which is detected in the plasma during viral infections and other pathological conditions also stimulates the capacity of endothelial cells to produce $\mathrm{PGI}_{2}$. Cultured BAEC that responded to the antiproliferative and antiviral activities of the IFN showed a significant enhancement in their capacity to produce $\mathrm{PGI}_{2}$. This effect was observed with cells pretreated with IFN for $24 \mathrm{~h}$ or longer and was dependent upon the IFN concentration. Several specific treatments of the human leukocyte IFN and the ineffectiveness of mouse IFN produced by $\mathrm{L}$ cells indicated that the effect was specific to IFN and not due to contaminants in the IFN preparation. BAEC can also produce very small quantities of $\mathrm{TXA}_{2}$ and $\mathrm{PGE}_{2}$ (15). This residual production appeared not to be affected by pretreating the cells with IFN.

In the experiments described above, IFN-treated cells were stimulated to produce $\mathrm{PGI}_{2}$ by the addition of arachidonic acid, a substrate for PG synthesis. Endothelial cells, as well as other cultured cells, can also spontaneously release PGs into the growth medium (15). This spontaneous release was not affected by IFN in BAEC cultures. In contrast, IFN has been previously shown to stimulate the spontaneous release of $\mathrm{PGE}_{2}$ from cultured fibroblasts $(7,9)$. This difference between BAEC and fibroblasts may result from the lack of $\Delta 6$-desaturase activity in endothelial cells (27) which therefore depend on the supply of exogenous arachidonic acid for PG synthesis. In contrast, fibroblasts that express this enzyme can convert linoleic acid into arachidonic acid (27).

To elucidate the mechanism of the IFN-mediated stimulation of $\mathrm{PGI}_{2}$ synthesis in BAEC, different stimulators and inhibitors of the arachidonic acid cascade were tested. BAEC were stimulated with ionophore A23187, which activates the enzyme phospholipase $A_{2}$, and with the endoperoxide $\mathrm{PGH}_{2}$, which is a substrate for the enzyme $\mathrm{PGI}_{2}$ synthetase $(18,19)$. IFN-treated cells stimulated with the ionophore A23187 appear to produce higher amounts of $\mathrm{PGI}_{2}$ compared with the untreated cells. However, IFN had no effect on the production of $\mathrm{PGI}_{2}$ when stimulated by the endoperoxide $\mathrm{PGH}_{2}$, suggesting that IFN does not stimulate the final enzymatic reaction in the synthesis of $\mathrm{PGI}_{2}$. Treatment with indomethacin, a potent inhibitor of cy- 
clooxygenase, resulted in a marked suppression of the arachidonate-induced $\mathrm{PGI}_{2}$ production in both the control and IFNtreated cells. The increased arachidonate-stimulated $\mathrm{PGI}_{2}$ production by IFN-treated BAEC was markedly suppressed by both hydrocortisone and dexamethasone, while the suppression of the basal synthesis of $\mathrm{PGI}_{2}$ by these glucocorticoids in cells not treated with IFN was less pronounced. Treatment with glucocorticoids primarily affects the lipolytic activity of phospholipase $A_{2}$, which leads to the release of endogenous arachidonic acid from cellular lipids (28). The finding that glucocorticoids inhibited $\mathrm{PGI}_{2}$ production in IFN-treated BAEC suggests that the exogenous arachidonic acid was first incorporated into membrane phospholipids and only then released by phospholipase $\mathrm{A}_{2}$ and converted to $\mathrm{PGI}_{2}$ by the cyclooxygenase. A similar phenomenon was described by Fuse et al. (9) who studied the effects of IFN on PGE synthesis in a fibroblast cell line GM258. They found that the IFN-mediated, increased production of PGE observed in the presence of exogenous arachidonic acid was almost completely inhibited by prednisolone, as compared with a smaller effect that glucocorticoids had on the basal production of PGE (9). Schwartzman et al. (29), who studied PG production in the isolated perfused rabbit kidney, have also found that exogenous arachidonic acid is first equilibrated with a membrane phospholipid pool and that the newly synthesized PG originate mainly from esterified arachidonate and less from conversion of the free exogenous arachidonate.

Our observations and the findings reported by Fuse et al. (9) that glucocorticoids primarily suppress the stimulated PG production in the IFN-treated cells suggest that IFN mainly stimulates the activity of phospholipase $A_{2}$. The results of experiments performed with other stimulators and inhibitors of the arachidonic acid cascade also support this conclusion. The finding that the expression of IFN enhancement of $\mathrm{PGI}_{2}$ production requires preincubation for at least $24 \mathrm{~h}$ and the observations of Fuse et al. that cycloheximide and actinomycin D inhibit the effect of IFN on PGE synthesis by fibroblasts, suggest a nuclear involvement in these activities of IFN. These findings may explain the lack of IFN effect on $\mathrm{TXA}_{2}$ production by unstimulated or aggregating platelets, since, owing to the lack of nucleus, platelets are not capable of mRNA synthesis. However, IFN may possibly have an effect on platelet $\mathrm{TXA}_{2}$ synthetase at the level of the bone marrow megakaryocytes, since these nucleated cells can produce $\mathrm{TXA}_{2}(30)$.

The biological significance of the IFN-mediated enhanced capacity of the endothelial cells to produce $\mathrm{PGI}_{2}$ requires further investigation in animals and man. It has been reported that PGs (PGA, PGE ${ }_{2}$ ) inhibit virus replication (31) and it is therefore possible that some of the antiviral activities of IFN are associated with PG's synthesis (30). Some support for this hypothesis may be derived from the finding that IFN-resistant mouse leukemia cell line was devoid of cyclooxygenase activity (32). However, in the cultured endothelial cell system, the antiviral activity was observed at IFN concentrations lower than those required for the enhancement of $\mathrm{PGI}_{2}$ synthesis. Both IFN and PG are inhibitors of cell proliferation $(6,33,34)$. The findings that similar concentrations of IFN are necessary for both the antiproliferative effect and the $\mathrm{PGI}_{2}$ enhancing activity suggest that these two activities may be associated. The increased $\mathrm{PGI}_{2}$ production capacity may also be involved in inhibition of platelet deposition on subendothelial structures that may be exposed during virus infection.

\section{Acknowledgments}

This research was supported by grants from the United States-Israel Binational Science Foundation (BSF) Jerusalem, Israel, and the A. Jurzykowski Foundation, NY., to Dr. Eldor, the National Institutes of Health (CA30280) to Dr. Vlodavsky, and the Volkswagen Stiftungwerk to Dr. Panet.

\section{References}

1. McKay, D. G., and W. Margaretten. 1967. Disseminated intravascular coagulation in virus diseases. Arch. Intern. Med. 120:125-152.

2. Curven, K. D., M. A. Gimbrone, and R. I. Handin. 1980. In vitro studies of thromboresistance: the role of prostacyclin $\left(\mathrm{PGI}_{2}\right)$ in platelet adhesion to cultured normal and virally transformed human vascular endothelial cells. Lab. Invest. 42:366-374.

3. Minick, C. R., G. G. Fabricant, J. Fabricant, and M. M. Litrenta. 1979. Atheroarteriosclerosis induced by infection with a herpes virus. Am. J. Pathol. 96:673-700.

4. Moncada, S., E. A. Higgs, and J. R. Vane. 1977. Human arterial and venous tissues generate prostacyclin (prostaglandin X), a potent inhibitor of platelet aggregation. Lancet. i:18-20.

5. Hamberg, M., J. Svensson, and B. Samuelsson. 1975. Thromboxanes: a new group of biological active compounds derived from prostaglandin endoperoxides. Proc. Natl. Acad. Sci. USA. 72:2994-2998.

6. Jameson, P. 1982. Induction of the interferon protein in vivo: viral inducers. In The Interferon System, Texas Reports in Biology and Medicine. S. Baron, F. Dianzani, and G. J. Stanton, editors. University of Texas Medical Branch at Galveston, Texas. 41:133-143.

7. Yaron, M., I. Yaron, D. Gurari-Rotman, M. Revel, H. R. Lindner, and U. Zor. 1977. Stimulation of prostaglandin $\mathrm{E}$ production in cultured human fibroblasts by poly (I)-poly (C) and human interferon. Nature (Lond.). 267:457-459.

8. Fitzpatrick, F. A., and D. A. Stringfellow. 1980. Virus and interferon effects on cellular prostaglandin biosynthesis. J. Immunol. 124:431-437.

9. Fuse, A., I. S. Mahmud, and T. Kuwata. 1982. Mechanism of stimulation by human interferon of prostaglandins synthesis in human cell lines. Cancer Res. 42:3209-3214.

10. Cantell, K., and S. Hirvonen. 1978. Large scale production of human leukocyte interferon containing $10^{8}$ units per ml. J. Gen. Virol. 39:541-543.

11. Paucker, K., B. J. Berman, R. R. Golgher, and D. Stancek. 1970. Purification, characterization and attempts at isotopic labeling of mouse interferon. J. Virol. 5:145-152.

12. Gospodarowicz, D., H. Bialecki, and G. Greenberg. 1978. Purification of fibroblast growth factor activity from bovine brain. J. Biol. Chem. 253:3736-3743.

13. Gospodarowicz, D., J. Moran, D. Braun, and C. Birdwell. 1976. Clonal growth of bovine vascular endothelial cells: fibroblast growth factor as a survival agent. Proc. Natl. Acad. Sci. USA. 73:4120-4124.

14. Vlodavsky, I., L. K. Johnson, G. Greenberg, and D. Gospo- 
darowicz. 1980. Vascular endothelial cells maintained in the absence of fibroblast growth factor undergo structural and functional alterations that are incompatible with their in vivo differentiated properties. J. Cell Biol. 83:468-486.

15. Eldor, A., I. Vlodavsky, E. Hy-Am, R. Atzmon, B. B. Weksler, A. Raz, and Z. Fuks. 1983. Cultured endothelial cells increase their capacity to synthesize prostacyclin following the formation of a contact inhibited cell monolayer. J. Cell Physiol. 114:179-183.

16. Gresser, I., M. R. Bandu, D. Broufy Boye, and M. Tovey. 1974. Pronounced antiviral activity of human interferon on bovine and porcine cells. Nature (Lond.). 251:543-545.

17. Borden, E. C., and P. H. Leohardt. 1977. A quantitative semimicro, semiautomated colorimetric assay for interferon. J. Lab. Clin. Med. 89:1036-1042.

18. Weksler, B. B., C. W. Ley, and E. A. Jaffe. 1978. Stimulation of endothelial cell prostacyclin production by thrombin, trypsin, and the ionophore A 23187. J. Clin. Invest. 62:923-930.

19. Marcus, A. J., B. B. Weksler, and E. A. Jaffe. 1979. Enzymatic conversion of prostaglandin endoperoxide $\mathrm{H}_{2}$ and arachidonic acid to prostacyclin by cultured human endothelial cells. J. Biol. Chem. 253:7138-7141.

20. Tovey, M. G., C. Rochette-Egly, and M. Castagna. 1979. Effect of interferon on concentrations of cyclic nucleotides in cultured cells. Proc. Natl. Acad. Sci. USA. 76:3890-3893.

21. Bougnoux, P., E. Bonvini, Z. L. Chang, and T. Hoffman. 1982. Effect of interferon on phospholipid methylation by peripheral blood mononuclear cells. J. Cell. Biochem. 20:215-223.

22. Eldor, A., I. Vlodavsky, E. Hy-Am, R. Atzmon, and Z. Fuks. 1983. The effect of radiation on prostacyclin $\left(\mathrm{PGI}_{2}\right)$ production by cultured endothelial cells. Prostaglandins. 25(2):263-280.

23. Ross, R., J. A. Glomset, B. Kariya, and L. Harker. 1974. A platelet dependent factor that stimulates the proliferation of arterial smooth muscle cells in vitro. Proc. Natl. Acad. Sci. USA. 71:1207-1210.
24. Coughlin, S. R., M. A. Moskowitz, and B. R. Zetler. 1980. Platelet dependent stimulation of prostacyclin synthesis by platelet derived growth factor. Nature (Lond.). 288:600-601.

25. Marcus, A. J., B. B. Weksler, E. A. Jaffe, and M. J. Broekman. 1980. Synthesis of prostacyclin from platelet-derived endoperoxides by cultured human endothelial cells. J. Clin. Invest. 66:979-986.

26. Weksler, B. B. 1982. Prostacyclin. Prog. Hemostasis Thromb. 6:113-138.

27. Spector, A. A., T. L. Kaduce, J. C. Hoak, and G. L. Fry. 1981. Utilization of arachidonic and linoleic acids by cultured human endothelial cells. J. Clin. Invest. 69:1003-1011.

28. Flower, R. J., and G. J. Blackwell. 1979. Anti-inflammatory steroids induce biosynthesis of a phospholipase $A_{2}$ inhibitor which prevents prostaglandin generation. Nature (Lond.). 278:456-459.

29. Schwartzman, M., E. Liberman, and A. Raz. 1981. Bradykinin and angiotensin II activation of arachidonic acid deacylation and prostaglandin $\mathrm{E}_{2}$ formation in rabbit kidney. J. Biol. Chem. 256:2329-2333.

30. Miller, J. L., M. J. Stuart, and R. W. Wallenga. 1982. Arachidonic acid metabolism in guinea pig megakaryocytes. Biochem. Biophys. Res. Commun. 107:752-759.

31. Santoro, M. G., G. Carruba, E. Garaci, B. M. Jaffe, and A. Benedetto. 1981. Prostaglandins of the A series inhibited Sendai Virus replication in cultured cells. J. Gen. Virol. 53:78-83.

32. Chandrabose, A. K., P. Cuatrecasas, R. Pottahil, and D. J. Lang. 1981. Interferon-resistant cell line lacks fatty acid cyclooxygenase activity. Science (Wash. DC). 212:329-331.

33. Hutter, J. J., E. T. Gwebu, R. U. Panganamola, G. E. Milo, and D. E. Cornwell. 1977. Fatty acids and their prostaglandin derivatives: inhibitors of proliferation in aortic smooth muscle cells. Science (Wash. DC). 197:289-290.

34. Hopkins, N. K., and R. R. Gorman. 1981. Regulation of 3T3L1 fibroblast differentiation by prostacyclin (prostaglandin I). Biochim. Biophys. Acta. 663:457-467. 